\title{
5. APPLICATION OF INTERACTIVE METHODS TO MUSIC AND LITERATURE LESSONS IN PRIMARY CLASSES
}

Tatiana Gînju ${ }^{261}$

\begin{abstract}
The author takes over and presents in the context of the action of integrating the literary-artistic education methodologies - the musical education methodologies the epistems that explain the interactive nature of these. This original way of approaching literature and arts methodologies has been applied experimentally in primary education, language courses and romanian literature and music education, thus providing teaching staff with integrated teaching and learning materials of literature and music.
\end{abstract}

Key words: methodology of literary-artistic education, methodology of musical education, integrating, interactive methods

\section{Introduction}

The implementation of the interactive methods in the primary education process in order to educate the pupils of the specific abilities of literary-artistic education - musical education (ELA-EM) has multiple value: facilitates reception-comprehension-interpretation of literary and musical works (although the educational approach is more complex than the separate teaching of literature and music), produces specific intercultural objectives (skills, characteristics, behaviors, literary-musical representations), develops the skills and talents in the field (which are innate).

On interactive (or active-participative) methods, as well as on instructional-educational methods in general, it is believed that they are somewhat separate from the subject of knowledge / the object of formationdevelopment. The question is epistemic, not methodological in nature, Vl. Pâslaru approaching it from the perspective of the subject-subject in knowledge (knowing, in his opinion, being identifiable with education). Hence, the author points out that "the origin of educational methodologies is in laws and principles, concepts and ideas" (Pâslaru, 2013, p.126; Morari, 2016, p.8-11).

\section{Discussions}

Reported to the subject of knowledge (literary and musical works), the specific ELA-EM methods can only be interactive, because the literary / musical works - any work of art does not open to the receiver other than through the active contribution of the receiver, which consists in the decoding of texts / scores and in the re-creation of the artistic image system of the work, thus being determined to interact with the systems of values of life experience and the literary and aesthetic values of the receptor (Jauss, 1983).

\footnotetext{
${ }^{261}$ Lecturer, Doctoral Candidate, „Alecu Russo” State University from Bălţi, Republic of Moldavia, e-mail tginju@list.ru
} 
However, it should be noted that not all ELA-EM methods are interactive / active-participatory. The literary analysis or inventory of some phenomena / elements of the work, the study of some sources about the opera are not necessarily active-participative and interactive methods. But it is precisely the active-participative and interactive character of some activities carried out sequentially in the literature / music lesson requiring the preliminary application of some methods of collecting and inventing the data / information about the work and the author, and only afterwards - having what - pupils can be trained in activity and interactive methods to express themselves constructively and creatively.

This approach to literary and artistic methodologies, including their interactive nature, is still unique at national and world level, and it is not even suggested by the well-known authors of books and treatises on educational methodologies / technologies.

The integration of ELA-EM methodologies is not limited to the development of new methods and procedures / techniques to stimulate pupils' training of artistic and aesthetic culture, but presupposes the valorisation and reconceptualization of existing methodologies. The engine of pupils training elements of artistic-aesthetic culture is the methodology developed on the interaction of literary-artistic education and musical education, validated by:

- principles of interaction and syncretism of arts;

- art receiver status of the second re-creative subject of the work;

- methods-processes / techniques-forms-means, determined by the interaction of the arts.

The stage of training-development of the literary-musical skills of our research included the realization of an experimental program of teaching music and literature in primary education, applying communicative teaching-learning technologies. As activities of formative value given by the interaction of literature and music have been designed and applied:

- Oral artistic communication;

- Written art communication;

- Perceiving and commenting on / interpreting artistic creations;

- Evaluating / appreciating art values;

- Composition of new literary / musical artistic creations.

Application methods have been put into interactive oral communication methods:

a) exhibit: exposition, description, narration, explanation, lecture;

b) conversational: conversation, discussion;

The pedagogical training for students of the primary classes of artistic and aesthetic culture was carried out in accordance with the initial theoretical assumptions / assumptions and based on the structure and components of the FCAE pedagogical model - the formation of the artistic-aesthetic culture.

Active-participatory methods applied to musical education lessons and Romanian language and literature in primary classes. 


\section{Question - answer in the bi-dialogical communication of the artistic characters}

Benefits:

a) no student is left out of the artistic action: some students are acting as actors and others - spectators - appreciators;

b) each student has the opportunity to record both individual successes and public successes through artistic action or appreciation-commentary;

c) communication is a creative-improvising character.

Scenario of the activity. One student puts the question in, and another responds; both students adhere to: a) the punctuation marks in the literary text; b) the cords of musical intonations. Other characters (students) are involved in the artistic action. Literary-musical communication:

I $\left\{\begin{array}{l}- \text { What's wrong with you, crap } \\ \text { Without rain, no wind, } \\ \text { With the branches to the ground? }\end{array}\right.$

II $\left\{\begin{array}{l}\text { - Why do not I bother, } \\ \text { If my time passes! }\end{array}\right.$

(M. Eminescu, What are you legalizing?)

\section{characters \\ Multi-dialogue communication with the participation of several artistic} Benefits:

a) the student's progress is assessed in relation to himself;

b) the scope of the objectives of the experimental program is broadened;

c) students work in a team, which allows the field of launch of new ideas / options to be expanded.

The conditions of the activity: the teacher proposes students the scenario of the literary story; presents the stimulating musical-artistic processes: rhythmic formulas that mimic the movements of the characters, syllables on which songs such as: "Vai, vai !, ah, ah! "cock-a-doodle-doo! saddle.

The literary-musical communication itself.

Teacher: Once a rabbit lived and had a beautiful, beautiful little house. But here comes the fox and your aviates (!) Puts out the bunny. The poor man is in the road and weeps: "Ah-ah-of-of "(!) (Sylables are played through melodious intonations with moody shades).

The character donkey: Would you have (!) Why are you crying, rabbit? (The character plays the "intonation of wonder / astonishment" and the characteristic rhythmic movements of the image) Let's give the fox out! (The rabbit and donkey go to the window of the cottage with ferocious rhythmic steps, but the fox does not listen to it).

The bear character: "Mur-mur-mur" (!) Why are you crying, rabbit? (The character melodically renders the "indignation of indignation / perplexity" and the rhythmic movements in question). Let's get the fox out! (The Bunny, The Bear, with heavy steps and donkey go to the window of the cottage, but the fox does not listen to it). 
The cock's character: cock-a-doodle-doo (!) Why are you crying, rabbit? (The character melodies "the indignation of indignation and the desire to stick with the fox" and the characteristic rhythmic movements). Let's get the fox out! (The rabbit, the teddy beard, with heavy steps, donkey and rooster with tortuous steps go to the window of the cottage.) The rooster ascended on the back of the colt cried out with a loud voice: cock-a-doodle-doo! Fox, come out to shout at me. the angry cock, the fox took it to the healthy). Such a teaching process is called rotational dialogue / dialogue "rondo", where the refrain (R - replica of the Rabbit) is repeated many times, and between these replicas appear the replicas of the other artistic characters, called episodes (E).

$\left(\mathrm{E}^{\mathrm{d}}\right)$ Cock-a-doodle-do!

(Ec) Ouch-ouch-ouch!

(R4) Ah-ah-ah!

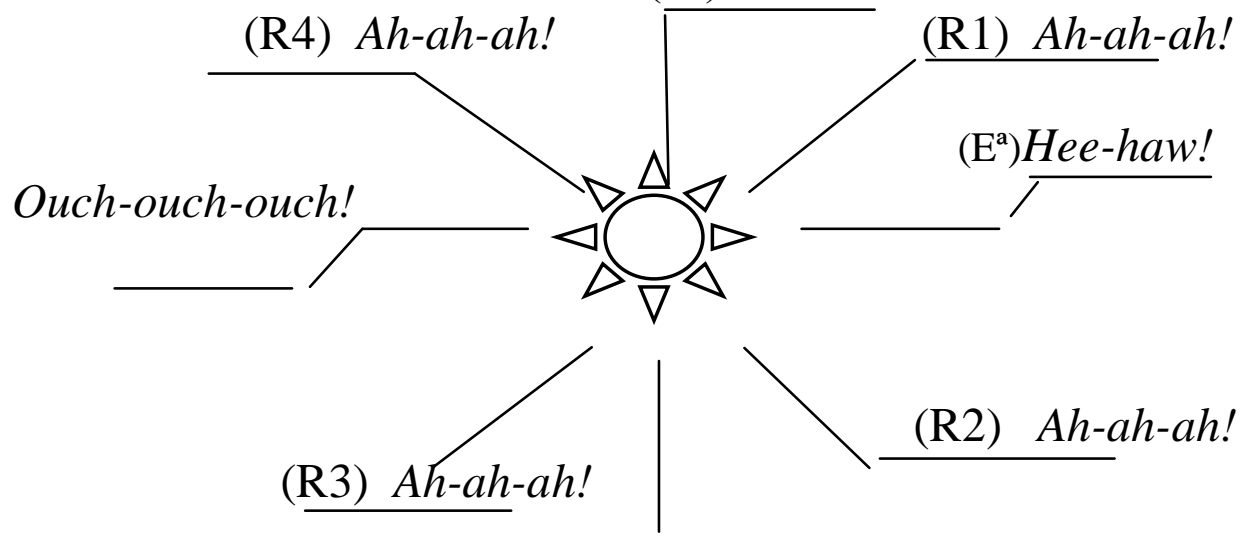

(E) Meow-meow-meow!

Fig. 1. The Literary-Musical Rondo

In order to evaluate the communication skills of the pupils of the second class, performing the role of a literary / musical character, the following quality assessment criteria were established:

a) artistic rendering / interpretation of character: character, behavior, characteristic intonations, movement, communication;

b) verbal-allegorical transfer and creation of the emotional state appropriate to the artistic painting;

c) the recitation / intonation of literary texts / musical tones in a manner appropriate to the literary-artistic painting;

d) the level of preservation / interpretation of literary-musical dramaturgy.

Quintet is a technique rather than a method and consists of creating a five-verse poem based on precise rules in order to synthesize the content of a topic addressed in concise expressions. The application rules for the music lesson are:

The first verse consists of one significant word, which denotes the subject (a noun). The second verse consists of two words describing the musical subject (adjectives). The third verse consists of three words that show actions (verb to gerund). The fourth verse is a four-sentence sentence to express what they feel about the subject (Cartaleanu, 2007). The last verse consists of a word with a finding or conclusion that expresses the essence of the subject (noun). The word 
should not be repeated in the other verses. Applying this method-techniques to the March of the Soldiers by P. Ceaikovsky:

- The march

- The military march

- The soldiers go marching

- The world is admiring the marching of the soldiers.

The quadrant method is a critical thinking method because it involves drawing two perpendicular lines in the middle of the sheet so that the four "quadrants" are formed in which students will write down the required information. They work individually or with the class divided by groups, each group receiving a file. Different requirements are formulated to achieve the objectives of the lesson (Cartaleanu, 2007). We propose a sample of quadrants as an example:

Quadrant I: Specifies the characters of the creature heard.

Quadrant II: Establishes and writes the main ideas / images of the creations heard.

Quadrant III: Write the morals / teachings that come out of the musical message.

Quadrant IV: Represents a drawing / scheme of motion of the melodic line of the first fragment / musical part of the audited work (D.Kabalevsky, Three Friends: Ștrengărița, Plângăreaţa, Răutăcioasa).

\begin{tabular}{|l|l|}
\hline $\begin{array}{l}\text { I. The frolicsome girl - character } \\
\text { with a unforeseeable behaviour; } \\
\text { The whining - pessimistic character; } \\
\text { The malicious - negative character; }\end{array}$ & $\begin{array}{l}\text { II. Diversified characters of the } \\
\text { personages, different characters }\end{array}$ \\
\hline $\begin{array}{l}\text { III. From the musical creation it is felt that the IV } \\
\text { characters of the personages differ a lot and each } \\
\text { from these has the right to existence, though The } \\
\text { Malicious will make troubles for those that } \\
\text { surround her }\end{array}$
\end{tabular}

Fig.1 Quadrant

At the next stage of the training experiment, the students of the 2nd class (exp. Lot) of the transdisciplinary competences were used: communicating to others the information obtained on the basis of the read texts and the auditory perception of the musical programs with the program (march, dance, song ).

\section{Transdisciplinary communication.}

Benefits:

a) the intervention of the frenzied factors and the express elaboration of measures to prevent unwanted obstacles are taken into consideration;

b) the area of literary and musical artistic stimuli extends;

c) Auditory and visual factors are significantly amplified in listeningcomparison-analysis-generalization;

d) advances the culture of perception and artistic thinking.

The pupils are presented with the literary text "I had a musician in honor, disappeared in a recreation, and what a musician it was! I see it, it was not like 
all the musicians. my father bought it, a lot of money gave her, he does not know I do not have it anymore, if he finds out, he would be angry with me. " Then students are offered to audition the creation Valles -joke (played by the musician) by D. Şostakovici.

In front of students, the following tasks are submitted:

- Communicate about the key words of the story - Students identify the words: the musician, disappeared, endowed with a changer, it was not like all the musicians.

- Listen carefully to the melody of the waltz and, following the text of the notes, carefully scratch the waltz song exactly - Students choose the similar phrases: 1 with no. 2; no. 3 with no. 4).

- Communicate the disposition of the character from the literary story "Muzicuţa" - Students describe two degrees of disposition, suggested by the literary text:

- the high mood of the character, motivated by a charming music that "was not like all the musicians", bought by his father with "a lot of money";

- the mood of the character, who regrets the music that "disappeared into a recreation."

- Communicate about the mood of "jungle"

Students see a joke, a mood for the charm of the music, the main reason "joke" is the melodic of the musical creation.

- Communicate what are the similarities or oppositions between these two artistic creations: literary text and musical text

Pupils, stimulated by the teacher, establish the following similarities:

- the first artistic creation predominates the mood of joy, happiness, the fulfillment of artistic dreams, although in the literary text one can observe the presence of a nostalgic provision of losing a nice object;

- In the second, jump by D.Sostakovici, the students also communicate the existence of two provisions: a joyful, joking, pitiful one.

Until this test was carried out, as well as the previous tests, a series of exercises were initiated to train students in similar formative actions. In particular, they were taken into account: the emotional reaction of pupils to artistic subjects (literary and musical); the way of perceiving, understanding the communication of those sensed by reading / listening music; the students' ability to create new attitudes-relationships between the read / received artistic subjects.

As for the formation of the description skills, comparisons have been developed through the Perception of the Read / Hear Artistic Message by the appropriate reception of the emotional and aesthetic universe of the literary / musical texts and the utility of the non-literary means. Entrance into the secrets of reading / listening and creating new literary-musical products.

Options:

a) description by the students of the literary content of a song highlighting the poetic valences of the text;

b) Comparing the artistic works received and characterizing the differences or similarities; 
c) expressing your own impressions and feelings about musical work;

d) composing new literary texts, improvising on these texts new intonations / musical melodies.

Content of the test. The pupils were offered to receive the literary text "Greieraş" de D. Dragan:

My crap in the house

She wears silk coat.

His song,

It looks like a bumper,
It would seem like a slumber

Under the porch of the ladder,

With his dew-boots,

Slipping under the new moon.

Task 1. To identify on the basis of artistic experience previously accumulated the phenomena: spatial state, temporal state and static state of the literary dramatic speech. To make such a composite appreciation, in advance with the students of the experimental classes, a series of exercises-trainings were carried out, which guided the students towards a profound and wide appreciation of even the smallest literary text. In such exercises predominated:

1. internal factors: culture of student thinking, culture of perception, personality qualities;

2. external factors: principles, methods and techniques (general and specific) to stimulate the student's artistic action.

The appreciation of the literary text was based on the use of artistic means in related fields, such as means of rendering space states, temporal states present in the reception of musical creations; as well as using the means of playing static states - characteristic of the field of plastic art. The following key moments have been highlighted in order to educate young pupils on integrated transdisciplinary reception and appreciation skills: encompassing the whole in the appreciation of artistic creation, determining the details (words, phrases, motives), and their role in playing the message integrated dramaturgy.

By applying to the lessons of musical education, language and artistic literature of interdisciplinary methodological tools (presented in the FCAE Pedagogical Model), we have succeeded in giving the pupils of the elements of artistic and aesthetic culture a growing dynamism, supported by both students, as well as from teacher-trainers. Significant in this respect remains the desideratum of experimental activity - to dynamize the student in the formative ambiance of the teacher himself, which implies change, increasing and continuous performance.

\section{Conclusions}

The development of the formative experiment demonstrated that by applying specific methodologies of interaction of literature with music, on the one hand, and the formation of the elements of the literary-musical culture, on the other, it develops the emotions and artistic experiences of the pupils.

In the same context, the application of interactive methods (which represent manifestations of ELA-EM interaction) requires the teacher to know the theoretical framework of inter-transdisciplinarity - literary interactions, the 
ability to structure hierarchically for each lesson all types of literary-musical ties, on the one hand, and the work - reader / auditor, on the other.

\section{Bibliography}

1. Cartaleanu, T. (2007). Predarea interactivă centrată pe elev. Ghid metodologic. Chişinău: Editura Ştiinţa.

2. Cerghit, I. (1973). Metode de învăţământ. Bucuresti: E.D.P.

3. Cristea, S. (1998). Dicționar de termini pedagogici. București: E.D.P.

4. Gagim, I. (2007). Ştiinţa şi arta educaţiei muzicale. Chişinău: Editura ARC.

5. Jauss, H.-R.(1983). Experienţă estetică şi hermeneutică literară. București: Editura Univers.

6. Morari, M., Pâslaru, Vl., Alexeeva, L. ș.a. (2016). Educația artistică în preșcolaritate. Ghid teoretico-metodologic. Chișinău: Pontos.

7. Neacșu, I. (2015). Metode și tehnici de invățare eficientă. Fundamente și practice de success. Iași: Editura Polirom.

8. Oprea, C. (1998). Strategii didactice interactive, București: E.D.P.

9. Pașca, E-M. (2008). Dimensiuni ale educației artistice. Mozaic educațional. Vol II. Iași: Editura Artes.

10. Pâslaru, Vl. (2013). Introducere în teoria educaţiei literar-artistice, București: Sigma. 